\title{
Pengaruh kemandirian belajar, minat belajar, disiplin belajar dan lingkungan belajar terhadap hasil belajar siswa
}

\author{
Fitri Rahayu ${ }^{\text {a, }}{ }^{*}$ \\ a Magister Pendidikan IPS Sekolah Tinggi Keguruan dan Ilmu Pendidikan PGRI Tulungagung. Indonesia \\ 1 firirahayu@gmail.com* \\ *korespondensi penulis
}

\begin{tabular}{ll}
\hline Informasi artikel & ABSTRAK \\
\hline Kata kunci: & Penelitian ini meneliti apakah ada pengaruh kemandirian belajar, minat belajar, disiplin \\
Kemandirian & belajar dan lingkungan belajar terhadap hasil belajar siswa khususnya pada mata pelajaran \\
belajar & Ilmu Pengetahuan Sosial (IPS) kelas VIII Di SMPN 2 Pakel tahun Pelajaran 2016/2017. \\
Minat belajar, & Penelitian ini dilakukan dengan menggunakan metode penelitian kuantitatif. Pengambilan \\
Disiplin belajar, & sampel menggunakan teknik proportional random sampling. Teknik pengumpulan data \\
Lingkungan & yang digunakan dalam penelitian ini adalah metode angket dan metode dokumentasi. \\
belajar, & Teknik analisis data yang digunakan dalam penelitian ini adalah analisis regresi linier \\
Hasil belajar & berganda, produk momen, uji t, uji F dan uji R2 dengan menggunakan bantuan program \\
& SPSS 23.0, for windows. Dilihat dari analisis linier berganda dengan hasil kemandirian \\
& belajar berpengaruh terhadap hasil belajar sebesar 1,300 lebih besar dari tabel 0.679 \\
& hubungan positif sebesar 0,661 nilai signifikan 0,002, minat belajar sebesar 0,738 lebih \\
& besar dari tabel 0.679 hubungan positif sebesar 0,835 nilai signifikan 0,003, disiplin belajar \\
& sebesar 1,466 lebih besar dari t tabel 0.679 hubungan positif sebesar 0.716 nilai signifikan \\
& 0,001 dan lingkungan belajar 0,087 lebih kecil dari tabel 0.679 hubungan positif sebesar \\
& 0,604 nilai signifikan 0,004.
\end{tabular}

Keywords: ABSTRACT

Learning interest,

This study examines whether there is influence of learning independence, interest in

Learning

discipline,

Learning

environment,

Learning

outcomes

learning, learning discipline and learning environment to student learning outcomes especially in Social Sciences subjects (IPS) class VIII In SMPN 2 Pakel Lesson 2016/2017.

This research is done by using quantitative research method. Sampling using propotional random sampling technique. Data collection techniques used in this study is a questionnaire method and documentation method. Data analysis techniques used in this study are multiple linear regression analysis, product moment, $t$ test, $F$ test and $R 2$ test using SPSS 23.0, for windows. Judging from the multiple linear analysis with the result of learning independence have an effect on the result of learning equal to 1,300 bigger than $t_{\text {tabel }} 0,679$ positive relation 0,661 significant value 0,002, study interest equal to 0,738 bigger than $t_{\text {tabe }}$ 0,679 positive relation 0,835 significant value 0,003, discipline learn equal to 1,466 more big from $t_{\text {tabel }} 0,679$ positive relationship equal to 0,716 significant value 0,001 and learning environment 0,087 smaller than $t_{\text {tabel }} 0,679$ positive relation 0,604 significant value 0,004 .

Copyright (C) 2018 Fitri Rahayu. All Right Reserved

\section{PENDAHULUAN}

Hasil belajar harus menunjukkan suatu perubahan tingkah laku yang bersifat menetap, fungsional, positif dan disadari. Perwujudan hasil belajar akan selalu berkaitan dengan kegiatan evaluasi. Menurut Slameto (2008, hal. 7) "hasil belajar adalah sesuatu yang diperoleh dari suatu proses usaha setelah melakukan kegiatan belajar yang dapat diukur dengan menggunakan tes guna melihat kemajuan siswa”. Lebih lanjut Slameto (2008, hal. 8) mengemukakan bahwa” hasil belajar diukur dengan rata-rata hasil tes yang diberikan dan tes hasil belajar itu sendiri 
adalah sekelompok pertanyaan atau tugastugas yang harus dijawab atau diselesaikan oleh siswa dengan tujuan mengukur kemajuan belajar siswa”. Untuk itu diperlukan teknik dan prosedur evaluasi belajar yang dapat menilai secara efektif proses dan hasil belajar. Pendapat Mudjijo (1995, hal. 29) mengenai tes hasil belajar yaitu” tes hasil belajar bermaksud untuk mengukur sejauh mana para siswa telah menguasai atau mencapai tujuantujuan pengajaran yang telah ditetapkan”. Akan tetapi memang ada beberapa siswa yang mengalami atau memiliki hasil belajar yang kurang baik yang bisa dipengaruhi dari banyak faktor tentunya. Ada beberapa faktor yang mempengaruhi hasil belajar siswa, salah satunya cara belajar yang salah, kurang adanya minat dalam belajar, kurangnya disiplin belajar dan faktor lingkungan. Jadi melihat situasi seperti itu guru dapat memberikan suatu rangsangan yang tepat bagi para siswa untuk meningkatkan cara belajar yang benar, dengan cara kemandirian belajar.

Kemandirian belajar ini mampu memberikan efek positif bagi siswa yang cara belajarnya salah, karena dengan siswa menerapkan kemandirian belajar siswa akan paham benar tugas-tugasnya sebagai pelajar. Kemandirian belajar sangat diperlukan dalam proses belajar siswa seperti yang dikemukakan Suryadi (2006, hal. 1) bahwa "siswa dengan kemandirian belajarnya tinggi akan berusaha bertanggung jawab untuk kemajuan prestasinya, mengatur diri sendiri memiliki inisiatif dan memiliki dorongan yang kuat untuk terus mengukir prestasinya”. sedangkan kemandirian belajar seperti yang diungkapkan Good (Slameto, 2013, hal. 2) "kemandirian belajar adalah belajar yang dilakukan dengan sedikit atau sama sekali tanpa bantuan dari pihak luar”. Seorang guru dituntut untuk meningkatkan kemandirian belajar siswa, dalam kaitannya dengan belajar mandiri diperlukan sekali akan adanya dorongan yang mampu merangsang untuk mau belajar mandiri.

Belajar mandiri memerlukan minat belajar yang lebih kompleks. Diakui atau tidak sebenarnya ada faktor-faktor yang mendorong untuk belajar mandiri bukan hanya dari dalam diri sendiri tetapi ada faktor dari luar yaitu seorang guru yang juga mempunyai andil dalam penyemangat siswa, dan mengetahui langkah apa yang dilakukan untuk menghadapi siswa dalam upaya meningkatkan kemandirian belajar. Para siswa belajar dengan kecepatan yang berbedabeda, dan belajar dalam cara yang berbedabeda pula. Mereka memiliki minat yang berbeda-beda dan miliki bakat yang khusus. Karena manusia adalah unik, maka tampaknya jika sekolah mengharapkan para siswa untuk belajar dalam situasi yang sama untuk mengali minat-minat pribadi dan mengembangkan bakat mereka dengan menggunakan kecerdasan mereka. Minat dapat timbul dengan sendirinya, yang ditengarai dengan adanya rasa suka terhadap sesuatu. Sedangkan menurut Dalyono (1996, hal. 56-57) “minat belajar yang besar 
cenderung menghasilkan prestasi yang tinggi, sebaliknya minat belajar yang kurang akan menghasilkan prestasi yang rendah” sedangkan menurut DEPDIKNAS (2003, hal. 60) "minat belajar adalah pilihan kesenangan dalam melakukan kegiatan dan dapat membangkitkan gairah seseorang untuk memenuhi kesediaannya yang dapat diukur melalui kesukacitaan, ketertarikan, perhatian, dan keterlibatan”. Minat merupakan rasa lebih suka dan rasa ketertarikan pada suatu hal atau aktivitas, tanpa ada yang menyuruh.

Minat siswa datang dalam dirinya dengan adanya dorongan yang kuat untuk selalu ingin tahu terhadap sesuatu yang menurutnya menarik atau yang ia sukai. Hal ini menunjukkan bahwa anak yang memiliki minat belajar akan meluangkan waktu belajar lebih banyak dan lebih tekun daripada mereka yang kurang memiliki atau sama sekali tidak mempunyai belajar. Anak akan terdorong dan tergerak untuk memulai aktivitas atas kemauannya sendiri, menyelesaikan tugas tepat waktu dan gigih, serta tidak putus asa saat menjumpai kesulitan dalam menjalankan tugas. Minat memberikan dorongan dan rasa senang, ketertarikan terhadap sesuatu, ketertarikan seseorang terhadap sesuatu karena sesuatu tersebut mampu menimbulkan perasaan senang, perasaan akan haus keingintahuan akan membuat siswa lebih semangat dalam belajar terutamanya belajar ilmu Pengetahuan sosial (IPS) karena bisa kita lihat ilmu pengetahuan sosial banyak sekali manfaatnya dalam kehidupan kita sehari hari.
Ketika seseorang menyadari bahwa kegemaraanya atau kesukaanya mampu memberikan suatu manfaat, dan ketika ditekuni atau ia lakukan mampu memberikan nilai atau hasil yang memuaskan maka hal tersebut akan mendatangkan kepuasan dan semangat akan sesuatu yang ia minati. Ditambah lagi kemandirian belajar dan minat belajar terhadap IPS mampu memberikan pengaruh dalam hasil belajar yang signifikan akan tetapi perlu kita ketahui, sebuah minat itu harus digali terus menerus karena untuk mendapatkan hasil belajar yang bagus bahkan jika kedua ini dilakukan bersama-sama bisa juga mempengaruhi hasil belajar yang sangat memuaskan.

Bukan hanya kemandirian belajar dan minat belajar saja yang harus dikembangkan, namun kedisiplinan dalam belajar perlu ditingkatkan seperti pendapat menurut Sanjaya (2005, hal. 9) “disiplin belajar hal yang sangatlah diperlukan bagi setiap siswa, dengan adanya disiplin belajar, tujuan pendidikan akan lebih mudah tercapai “. Selanjutnya menurut Tu’u (2004, hal. 163) yang menyatakan bahwa: "disiplin belajar akan berdampak positif bagi kehidupan siswa, mendorong mereka belajar konkret dalam praktik hidup di sekolah serta dapat beradaptasi”. Belajar dengan disiplin yang terarah dapat menghindarkan diri dari rasa malas dan menimbulkan kegairahan siswa dalam belajar, yang pada akhirnya akan dapat meningkatkan daya kemampuan belajar siswa. Disiplin merupakan kunci sukses dan 
keberhasilan. Dengan disiplin seseorang menjadi yakin bahwa disiplin akan membawa manfaat yang dibuktikan dengan tindakannya.

Setelah berperilaku disiplin, seseorang akan dapat merasakan bahwa disiplin itu pahit tetapi buahnya manis. Disiplin memberikan manfaat yang besar dalam diri seseorang. Sepintas bila kita mendengar kata disiplin maka yang selalu terbayang usaha untuk menyekat, mengawal dan menahan. Padahal tidak demikian, sebab disiplin bermakna melatih, mendidik dan mengatur atau hidup teratur. Artinya kata disiplin itu tidak terkandung makna sekatan, tetapi juga latihan. Untuk itulah kedisiplinan sangat diperlukan dalam usaha meningkatkan suatu kehidupan yang teratur dan meningkatkan prestasi dalam belajar karena sifatnya yang mengatur dan mendidik.

Dari kebanyakan orang-orang sukses rasanya tidak ada diantara mereka yang tidak berdisiplin, kedisiplinan yang tertanam dalam setiap kegiatan mereka yang membawa kesuksesan. Tetapi faktor lingkungan juga ikut andil dalam kegiatan pembelajaran siswa, sesuai pendapat Saroni dalam Jamal (2011, hal. 110) "lingkungan belajar adalah segala sesuatu yang berhubungan dengan tempat proses pembelajaran dilaksanakan”. Sedangkan menurut Slameto (2003: 60) mengemukakan bahwa "lingkungan belajar siswa yang berpengaruh terhadap hasil belajar siswa terdiri dari lingkungan keluarga, lingkungan sekolah dan lingkungan masyarakat”. Bahwa lingkungan belajar juga mampu memberikan kontribusi terhadap hasil belajar siswa, terlebih lagi tempat penelitian ini bertempat di SMPN 2 Pakel yang mayoritas siswa-siswa nya lebih suka berteman bergerombol atau secara berkelompok, ini akan mempengaruhi dalam hasil belajar. Bisa kita ambil contoh satu gerombolan siswa menyukai mata pelajaran IPS, ia akan senantiasa bertukar pikiran saling mencari tahu mengenai pelajaran tersebut dan saling memberi Inovasi satu sama lain karena mereka menggagap mereka satu pemikiran yaitu menyukai mata pelajaran IPS, sedangkan satu kelompok lagi adalah satu kelompok siswa yang salah satu dari anggota gerombolan itu adalah seorang siswa yang suka membolos waktu pelajaran, karena alasannya ia tidak suka dengan mata pelajaran tersebut yang menurutnya mata pelajaran itu sangat membosankan, lama kelamaan kebiasaan ini akan mempengaruhi atau menular ke anggota gerombolan itu. Jika ini terjadi terus menurus, dan banyak siswa berpikiran sama dengan teman yang memberi pengaruh buruk akan berdampak kepada hasil belajar siswa.

Rendahnya hasil belajar dapat dilihat dari nilai ulangan harian, tugas-tugas yang diberikan guru dan ujian semester yang terhitung kurang memuaskan. Faktor penentu keberhasilan dalam belajar adalah siswa sebagai pelaku dalam kegiatan belajar. Tanpa kesadaran, kemauan, dan keterlibatan siswa, maka proses belajar tidak akan berhasil. Dengan demikian dalam belajar, siswa 
dituntut memiliki sikap mandiri, artinya siswa perlu memiliki kesadaran, kemauan dan motivasi dari dalam diri siswa dan bukan semata-mata tekanan orang tua maupun pihak lain. Dengan adanya sikap mandiri dalam diri siswa, tujuan belajar akan berhasil dicapai sebagaimana yang diharapkan. Selain itu didukung dengan minat belajar yang tinggi dorongan yang kuat akan menimbulkan kesukaan terhadap mata pelajaran akan memberikan efek kesenangan tersendiri terhadap siswa tersebut secara perlahan kedisiplinan belajar itu akan terus terjadi tanpa harus ada paksaan, lingkungan belajar yang mendukung akan mempermudah siswa untuk lebih giat lagi dalam memperoleh hasil belajar yang baik dan diharapkan dimana tempat belajar siswa yaitu lingkungan sekolah mampu memberikan pengaruh positif terhadap kegiatan pembelajaran siswa dengan seperti itu hasil belajar siswa akan lebih baik.

\section{METODE}

Penelitian ini dilaksanakan di SMP Negeri 2 Pakel. Secara geografis, SMP Negeri

2 Pakel beralamatkan di desa Gesikan dk. Gresik kecamatan Pakel Kabupaten Tulungagung. Berdasarkan jenisnya penelitian ini merupakan penelitian kuantitatif. Berdasarkan sifatnya penelitian ini dinamakan penelitian deskriptif korelasional”.

Penelitian ini menggunakan metode expost facto di mana data yang akan dikumpulkan tidak memerlukan eksperimen melainkan sudah ada pada diri siswa. Penelitian ini menggunakan analisis statistik deskriptif untuk menggambarkan tentang kondisi objektif Kemandirian belajar, minat belajar, disiplin belajar, lingkungan belajar terhadap hasil belajar IPS.

Populasi dalam penelitian ini adalah seluruh siswa kelas VIII SMPN 2 PAKEL yang berjumlah 127 siswa yang terbagi menjadi 6 kelas yaitu VIII A, VIII B, VIII C, VIII D, VIII E dan VIII F.

\section{HASIL DAN PEMBAHASAN}

Hasil dari pengujian regresi linier berganda adalah 104,799 dengan tingkat signifikansi adalah 0,000 hal ini berarti bahwa terdapat hubungan yang erat antara kemandirian belajar, minat belajar, disiplin belajar dan lingkungan belajar terhadap hasil belajar siswa kelas VIII SMPN 2 Pakel pada mata pelajaran IPS Tahun pelajaran 2016/2017.

Dari hasil uji regresi linier berganda dapat dilihat dari table coefficients, diperoleh persamaan $\mathrm{Y}=\mathrm{a}+\mathrm{b} x_{1}+\mathrm{b} x_{2}+\mathrm{b} x_{3}+\mathrm{b} x_{4}$ maka dari hasil perhitungan didapat: $\mathrm{Y}=104.799+$ $0.479 x_{1}+0.569 x_{2}+1.308 x_{3}+0.044 x_{4}$

1) (a) merupakan konstanta yang besarnya 104.799 menyatakan bahwa jika variabel independen (kemandirian belajar, minat belajar, disiplin belajar dan lingkungan belajar) sebesar nol (0), maka nilai variabel dependen (hasil belajar) sebesar 104.799

2) $\left(b_{1}\right)$ merupakan koefisien regresi dari $x_{1} 0.479$ menyatakan bahwa setiap penambahan satu satuan variabel kemandirian belajar, maka hal ini akan 
berpengaruh peningkatan besarnya hasil belajar sebesar0.479 dengan asumsi variabel lain konstan.

3) $\left(b_{2}\right)$ merupakan koefisien regresi dari $x_{2} 0.569$ menyatakan bahwa setiap penambahan satu satuan variabel minatbelajar, maka hal ini akan berpengaruh peningkatan besarnya hasil belajar sebesar 0.569 dengan asumsi variabel lain konstan.

4) $\left(b_{3}\right)$ merupakan koefisien regresi dari $x_{3} 1.308$ menyatakan bahwa setiap penambahan satu satuan variabel disiplin belajar, maka hal ini akan berpengaruh peningkatan besarnya hasil belajar sebesar 1.308 dengan asumsi variabel lain konstan.

5) $\left(b_{4}\right)$ merupakan koefisien regresi dari $x_{4} 0.044$ menyatakan bahwa setiap penambahan satu satuan variabel lingkungan belajar, maka hal ini akan berpengaruh peningkatan besarnya hasil belajar sebesar 0.044 dengan asumsi variabel lain konstan.

Hasil uji korelasi hasil belajar dengan kemandirian belajar $0.661>0.2075$, hal ini berarti bahwa terdapat hubungan positif antara hasil belajar dengan kemandirian belajar

Hasil uji korelasi hasil belajar dengan minat belajar $0.835>0.2075$ hal ini berarti bahwa terdapat hubungan positif antara hasil belajar dengan disiplin belajar

Hasil uji korelasi hasil belajar dengan disiplin belajar $0.716>0.2075$ hal ini berarti bahwa terdapat hubungan positif antara hasil belajar dengan minat belajar

Hasil uji korelasi hasil belajar dengan lingkungan belajar $0.604>0.2075$ hal ini berarti bahwa terdapat hubungan positif antara hasil belajar dengan lingkungan belajar.

Hasil distribusi $t$ (thitung) kemudian dibandingkan dengan table distribusi kemudian daerah penerimaan dan penolakan sebagai berikut: Jika hasil thitung $>\mathrm{t}$ table: maka $\mathrm{H}_{\mathrm{o}}$ di tolak, artinya berarti terdapat pengaruh yang signifikan antara variabel $x$ dengan variabel $y$.

Hasil $1.300 \geq 0.679$ : maka $\mathrm{H}_{\mathrm{o}}$ ditolak dan $\mathrm{H}_{\mathrm{a}}$ diterima Terdapat pengaruh yang signifikan antara kemandirian belajar terhadap hasil belaja siswa kelas VIII SMPN 2 Pakel pada mata pelajaran IPS Tahun pelajaran 2016/2017.

Hasil $0.738 \geq 0.679$ : maka $\mathrm{H}_{\mathrm{o}}$ ditolak dan $\mathrm{H}_{\mathrm{a}}$ diterima Terdapat pengaruh yang signifikan antara minat belajar terhadap hasil belaja siswa kelas VIII SMPN 2 Pakel pada mata pelajaran IPS Tahun pelajaran 2016/2017.

Hasil $1.466 \geq 0.679$ : maka $\mathrm{H}_{\mathrm{o}}$ ditolak dan $\mathrm{H}_{\mathrm{a}}$ diterima Terdapat pengaruh yang signifikan antara disiplin belajar terhadap hasil belaja siswa kelas VIII SMPN 2 Pakel pada mata pelajaran IPS Tahun pelajaran 2016/2017.

Hasil $0.087 \geq 0.679$ : maka $H_{o}$ ditolak dan $\mathrm{H}_{\mathrm{a}}$ diterima Tidak terdapat pengaruh yang signifikan antara lingkungan belajar terhadap 
hasil belaja siswa kelas VIII SMPN 2 Pake b. Dependent Variable: NILAI

pada mata pelajaran IPS Tahun pelajaran 2016/2017.

Untuk menentukan $F_{\text {tabel }}$ yaitu dengan menggunakan tingkat keyakinan 95\%, $\alpha=$ $5 \%$, df 1 (jumlah variabel-1) atau 3-1 =2 df 2 (n-k-1) atau 64-2-1 = 61 Hasil diperoleh untuk Ftabel sebesar 1.83. Berdasarkan hasil penghitungan dengan bantuan progam SPSS 23.0 diperoleh hasil sebagai berikut:

\begin{tabular}{|c|c|c|c|c|c|}
\hline Model & Sum of Squares & $\mathrm{df}$ & Mean Square & $\bar{F}$ & Sig. \\
\hline \begin{tabular}{|ll}
11 & Regression \\
\end{tabular} & 236,517 & 4 & 59,129 & 7,431 &, $002^{3}$ \\
\hline Residual & 2438,483 & 59 & 41,330 & & \\
\hline Total & 2675,000 & 63 & & & \\
\hline
\end{tabular}

Dari tabel ANOVA diatas menunjukkan dengan nilai signifikan 0,002 dan (7.431) > (1.83), maka $\mathrm{H}_{\mathrm{o}}$ ditolak dan $\mathrm{H}_{\mathrm{a}}$ diterima. Terdapat hubungan antara kemandirian belajar, minat belajar, disiplin belajar dan lingkungan belajar terhadap hasil belajar siswa kelas VIII SMPN 2 Pakel pada mata pelajaran IPS Tahun pelajaran 2016/2017.

Angka yang digunakan dalam penilaian interpretasi adalah nilai $\mathrm{R}$ dari data tabel Model Summary dengan hasil sebagai berikut:

\section{Hasil Uji Koefisien Determinasi}

\begin{tabular}{|l|c|l|l|l|}
\hline & & & Adjuste & Std. \\
Model & $\mathrm{R}$ & Square & Error of \\
$\mathrm{R}$ & Square & Estimate \\
\hline 1 & $\begin{array}{l}\text {, } 297 \\
\text { a }\end{array}$ &, 880 &, 27 & 6,429 \\
\hline
\end{tabular}

Berdasarkan nilai R Square sebesar 0,88 maka Pengaruh Ada pengaruh kemandirian belajar, minat belajar, disiplin belajar dan lingkungan belajar terhadap hasil belaja siswa kelas VIII SMPN 2 Pakel pada mata pelajaran IPS Tahun pelajaran 2016/2017 sebesar 88 \% sedangkan $12 \%$ adalah variabel lain yang tidak diteliti dalam penelitian.

Kemandirian belajar sangat diperlukan dalam proses belajar siswa seperti yang dikemukakan Suryadi (2006, hal.1) bahwa “siswa dengan kemandirian belajarnya tinggi akan berusaha bertanggung jawab untuk kemajuan prestasinya, mengatur diri sendiri memiliki inisiatif dan memiliki dorongan yang kuat untuk terus mengukir prestasinya”. Sedangkan kemandirian belajar Seperti yang diungkapkan Good dalam Slameto, (2013, hal. 2) "kemandirian belajar adalah belajar yang dilakukan dengan sedikit atau sama sekali tanpa bantuan dari pihak luar”.

Hasil pengaruh kemandirian belajar sesuai dengan perhitungan SPSS adalah 1.300, dimana apabila di bandingkan dengan nilai t-tabel yang berkisar di angka 0.681, nilai variabel kemandirian belajar lebih besar dan didukung dengan nilai signifikan pada hasil perhitungan SPSS 23.0 sebesar 0.002 maka dapat disimpulkan. Terdapat pengaruh yang signifikan antara kemandirian belajar terhadap hasil belaja siswa kelas VIII SMPN 2 Pakel pada mata pelajaran IPS Tahun

a. Predictors: (Constant), lingkungan, kemandirian, pelajaran 2016/2017. minat, disiplin. 
Menurut Dalyono (1996:56-57) “minat belajar yang besar cenderung menghasilkan prestasi yang tinggi, sebaliknya minat belajar yang kurang akan menghasilkan prestasi yang rendah”. Sedangkan menurut DEPDIKNAS, (2003:60) "minat belajar adalah pilihan kesenangan dalam melakukan kegiatan dan dapat membangkitkan gairah seseorang untuk memenuhi kesediaannya yang dapat diukur melalui kesukacitaan, ketertarikan, perhatian, dan keterlibatan'. Minat belajar memainkan peran yang penting dalam kehidupan siswa dan mempunyai dampak yang besar atas perilaku dan sikap siswa. Dalam meningkatkan minat belajar siswa tentunya pada mata pelajaran IPS.

Hasil pengaruh variabel minat belajar sesuai dengan perhitungan SPSS adalah 0.738, dimana apabila di bandingkan dengan nilai t-tabel yang berkisar di angka 0.681, nilai variabel minat lebih besar dan didukung dengan nilai signifikan pada hasil perhitungan SPSS 23.0 sebesar 0.004 maka dapat disimpulkan. Terdapat pengaruh yang signifikan antara minat belajar terhadap hasil belajar siswa kelas VIII SMPN 2 Pakel pada mata pelajaran IPS Tahun pelajaran 2016/2017.

Disiplin sangat penting dalam kegiatan belajar mengajar di sekolah. Sikap tersebut dapat menciptakan suasana belajar yang nyaman dan kondusif untuk belajar, hal ini diungkapkan pula oleh Tu’u (2004: 163) yang menyatakan bahwa: “disiplin belajar akan berdampak positif bagi kehidupan siswa, mendorong mereka belajar konkret dalam praktik hidup di sekolah serta dapat beradaptasi”.

Hasil pengaruh variabel disiplin belajar sesuai dengan perhitungan SPSS 23.0 adalah 1.466 dan merupakan pengaruh paling besar, dimana apabila di bandingkan dengan nilai tabel yang berkisar di angka 0.681, nilai variabel disiplin belajar lebih besar dan didukung dengan nilai signifikan pada hasil perhitungan SPSS 23.0 sebesar 0.001 maka dapat disimpulkan. Terdapat pengaruh yang signifikan antara disiplin belajar terhadap hasil belaja siswa kelas VIII SMPN 2 Pakel pada mata pelajaran IPS Tahun pelajaran 2016/2017.

Menurut Saroni dalam Jamal (2011:110) "lingkungan belajar adalah segala sesuatu yang berhubungan dengan tempat proses pembelajaran dilaksanakan”. Sedangkan menurut Slameto (2003: 60) mengemukakan bahwa "lingkungan belajar siswa yang berpengaruh terhadap belajar siswa terdiri dari lingkungan keluarga, lingkungan sekolah dan lingkungan masyarakat”. Sedangkan menurut Sidi (2005:148), "lingkungan belajar sangat berperan dalam menciptakan suasana belajar yang menyenangkan”.

Hasil pengaruh variabel lingkungan belajar sesuai dengan perhitungan SPSS 23.0 adalah 0.087, dimana apabila di bandingkan dengan nilai t-tabel yang berkisar di angka 0.681, nilai variabel lingkungan belajar lebih kecil dan didukung dengan nilai signifikan 
pada hasil perhitungan SPSS 23.0 sebesar 0.001 maka dapat disimpulkan. Tidak terdapat pengaruh yang signifikan antara lingkungan belajar terhadap hasil belajar siswa kelas VIII SMPN 2 Pakel pada mata pelajaran IPS Tahun pelajaran 2016/2017.

\section{SIMPULAN}

1. Terdapat pengaruh Kemandirian belajar terhadap hasil belajar siswa khususnya pada mata pelajaran IPS Kelas VIII Di SMPN 2 Pakel Tahun pelajaran 2016/2017. Sesuai dengan hasil perhitungan SPSS 23.0 dengan hasil 1.300 lebih besar dari nilai t-tabel 0.679 , mempunyai hubungan positif sebesar 0.661 dan didukung dengan nilai signifikan 0.002 .

2. Terdapat pengaruh Minat belajar terhadap hasil belajar siswa khususnya pada mata pelajaran IPS Kelas VIII Di SMPN 2 Pakel Tahun pelajaran 2016/2017. Sesuai dengan hasil perhitungan SPSS 23.0 dengan hasil 0.738 lebih besar dari nilai t-tabel 0.679 , mempunyai hubungan positif sebesar 0.835 dan didukung dengan nilai signifikan 0.003 .

3. Terdapat pengaruh Disiplin belajar terhadap hasil belajar siswa khususnya pada mata pelajaran IPS Di Kelas VIII Di SMPN 2 Pakel Tahun pelajaran 2016/2017. Sesuai dengan hasil perhitungan SPSS 23.0 dengan hasil 1.466 lebih besar dari nilai t-tabel 0.679 , mempunyai hubungan positif sebesar
0.716 dan didukung dengan nilai signifikan 0.001 .

4. Tidak terdapat pengaruh Lingkungan belajar terhadap Hasil belajar siswa khusunya pada mata pelajaran IPS Kelas VIII Di SMPN 2 Pakel Tahun pelajaran 2016/2017. Sesuai dengan hasil perhitungan SPSS 23.0 dengan hasil 0.087 lebih kecil dari nilai t-tabel 0.679 , mempunyai hubungan positif sebesar 0.604 dan didukung dengan nilai signifikan 0.004 .

5. Terdapat pengaruh Kemandirian belajar, Minat belajar, Disiplin belajar Dan Lingkungan belajar terhadap Hasil belajar khusunya pada mata pelajaran IPS Kelas VIII Di SMPN 2 Pakel Tahun pelajaran 2016/2017. Dari tabel ANOVA diatas menunjukkan dengan tingkat kelemahan 0,002 dan (7.431) > (1.83). Berdasarkan nilai R Square sebesar 0,088 maka Pengaruh Ada pengaruh kemandirian belajar, minat belajar, disiplin belajar dan lingkungan belajar terhadap hasil belajar siswa kelas VIII SMPN 2 Pakel pada mata pelajaran IPS Tahun pelajaran 2016/2017 sebesar 88 \% sedangkan $12 \%$ adalah variabel lain yang tidak diteliti dalam penelitian.

\section{DAFTAR PUSTAKA}

Apriatun.(2014). Makalah. Menumbuhkan Minat belajar pada siswa. Fakultas Keguruan dan Ilmu pendidikan: Universitas PGRI Yogyakarta

Data siswa tahun pelajaran 2016/2017 SMPN 2 Pakel 
Fatoni, A. (2015). Pengaruh perhatian orang tua, kemandirian belajar dan fasilitas belajar terhadap prestasi ekonomi akuntasi sisswa kelas XI IPS di SMAN 2 Re,namh tahun pelajaran 2014/2015. Tesis publish

Fatoni, M. (2016). Pengaruh kedisiplinan, minat belajar, dan perhatian orang tua terhadap prestasi belajar ips siswa smkn 1 godean tahun 2015/2016. Universitas Pgri Yogyakarta. Tesis Publish

Hakim, T.(2002). Belajar secara efektif. Jakarta: Puspa Suara

Majid. A. (2015). Penilaian autentik proses dan hasil belajar. Bandung: Remaja Rosdakarya

Putri. M. E. (2011). Pengaruh kebiasaan belajar persepsi siswa tentang metode mengajar guru terhadap prestasi belajar Ekonomi siswa Kelas X SMA $N$ 1 Patuk Gunung kidul Tahun Ajaran 2011/2012. Tesis Publish

Suryosubroto. (2009). Proses belajar mengajar di sekolah. Jakarta: Rineka Cipta

Slameto. (2003). Belajar dan faktor-faktor yang mempengaruhinya. Jakarta: Rineka Cipta

Sobri. M. (2014). Pengaruh kedisiplinan dan kemandirian belajar terhadap hasil belajar ekonomi Madrasah Aliyah di Kecamatan Praya. Jurnal Harmoni Sosial. I (1) (43-56). 